Duwi Adinda Prastiwi ${ }^{1}$, Moses Glorino Rumambo Pandin ${ }^{2}$

${ }^{1}$ Faculty of Nursing, University of Airlangga

${ }^{2}$ Faculty of Humanities, University Airlangga

Airlangga University Campus C, Jl.Mulyorejo, Mulyorejo, Surabaya, East Java 60115

duwi.adinda.prastiwi-2020@fkp.unair.ac.id; moses.glorino@fib.unair.ac.id

\title{
THE ROLE OF INDONESIAN MILLENNIALS ON PERCEPTION LAW AND DEMOCRACY
}

Title: Future Format (Notes on Indonesian Law and Democracy); Author: Dr. H. Muammar Arafat Yusmad, SH., MH.; Publisher: Deepublish Publisher (Publishing Group CV Budi Utama); City of publication: Yogyakarta; Edition: First published, October 2020; Electronic ISBN: 978-623-02-1886-6; Number of Pages: 104 Pages

During this millennial period, several problems related to ideological challenges in terms of Law, human rights, and corruption. Writing a book entitled Future Format (Notes on Indonesian Law and Democracy) by Dr. H. Muammar Arafat Yusmad, SH, MH was encouraged by the desire and hope of making real contributions as academics and researchers to advance the development of national Law. The book's title is inspired by the song by Dewa-19. The song teaches that all memories must be sincerely released from several excerpts and not burden the present. However, memories are not to be forgotten but will become material for self-evaluation in the present.

A book entitled Future Format (Notes on Indonesian Law and Democracy) is generally intended for all Indonesian people and the millennial generation. Because the role of millennials today in determining the journey of the Indonesian nation is very significant, it is hoped that the millennial power which acts as a pioneer can generate positive energy for the creation of a dignified democratic process (for example, elections). What millennials can do as a contribution to democracy in Indonesia, especially elections, is not to be apathetic and not abstain.

This book is the latest year (2020), containing material on various recent legal and democratic phenomena. For example, the elections that took place in 2019. Besides that, it also presents challenges to the Pancasila ideology, corruption, terrorism, human rights, etc. In addition to discussing legal phenomena, there are also legal foundations and solutions.

The book by Dr. H. Muammar Arafat Yusmad, SH, MH is very important to review because it presents the phenomena of Law and democracy. Law foundations and solutions accompany the phenomena of Law and democracy in this book, thereby increasing readers' knowledge of Indonesian Law. In addition, it can encourage the Indonesian people, especially millennials, to criticize the phenomenon of Law and democracy that is presented.

The role of millennials nowadays in determining the journey of the Indonesian nation is very significant because of the demographic bonus that Indonesia feels. It hopes that the millennial power, which acts as a pioneer, can generate positive energy to create a dignified democratic process (for example, elections). On a small scale, millennials can carry out democratization in their institutions safely and peacefully, for example, the election of BEM on campus, the election of leaders of youth and community organizations, etc.

In the Republic of Indonesia Law No. 40 of 2008, article 17 paragraph 3 states that the active role of youth as agents of change is manifested, among others, through political education and democracy. What millennials can do as a contribution to democracy in Indonesia, especially elections, is not to be apathetic and not to abstain from voting because elections are part of improving the economic and social system. Participating in elections is a sign of concern to participating in guarding the process of electing the nation's leader so that it does not fall into the hands of wrongdoers. Millennials must be at the forefront as guardians of national identity as a nation that likes cooperation, is tolerant, has a high sense of kinship and tolerance, and is polite in the democracy of Pancasila.

By participating in the election means implementing the values of Pancasila. The application of Pancasila values takes place dynamically along with the movement of Indonesian society towards a new civilization. In the millennial era, challenges to Pancasila as an ideology are not easy. For example, some want to replace Pancasila with other ideologies, and some want to separate Pancasila and religion. Despite experiencing many challenges, Pancasila is becoming stronger as the glue of 
national unity and forming Indonesia's national identity. It causes other ideologies which cannot replace Pancasila as an ideology.

The rule of Law assembles in a legal system based on Pancasila. The rule of Law of Pancasila has a philosophical meaning to build a religious society, just and civilized humanity, to unite the nation and be democratic that respects human rights with social justice. Law can be a means and guard community in its function as a means of social control and a means of social engineering.

In law enforcement, there must be innovation so that Indonesian law enforcement can progress. An example of innovation is by designing pro-people regional legal products. This regional regulation product is a strategic instrument in implementing regional autonomy that can distribute public opinion in the regions. Making pro-people regional legal products must pay attention to several things, including the regional head must be strongly committed to advancing and welfare of the people. These legal products are not made to seek money, burden the community on the pretext of levies/fees, and fulfill the principles of establishing legislation.

On pages xiv to xvii, it shows that the book fulfills readers' needs regarding the latest legal and democratic phenomena, such as elections, terrorism, corruption, human rights, omnibus Law, etc. It is expected that it will make readers criticize legal and democratic problems by finding the right solutions according to the readers so that readers can apply the values of Pancasila in the legal and democratic phenomena that occur.

A book entitled Future Format (Notes on Indonesian Law and Democracy) contains the latest legal and democratic phenomena, for example, elections, terrorism, corruption, omnibus Law, etc. The elections held in 2019 are a party of people's democracy. Millennials play a role by not being apathetic and not abstaining. Corruption is a legal problem that has never been resolved. Indeed, every year there are corrupt officials. For example, the Regent of Talaud (Sri Wahyuni MM) was caught in an OTT (hand-catching operation) on April 30, 2019. Corruption shows that the morale of officials is still low, thus committing corruption. Apart from the problem of corruption, terrorism is a serious problem in Indonesia.

The book by Dr. H. Muammar Arafat Yusmad, SH, MH is very influential for all Indonesian people facing legal and democratic phenomena, including the Pancasila ideology's challenges. In addition, it contains an overview of the laws and challenges of Pancasila and also provides solutions to deal with them.

Reading this book can increase readers' knowledge about the Law that governs the phenomenon of Indonesian Law and democracy. On the other hand, it encourages Indonesians, especially millennials, to criticize legal issues. In addition, it urges Indonesians to be more concerned with the challenges to the Pancasila ideology. For example, by applying Pancasila values in everyday life. So that Pancasila becomes a way of life and is not easily replaced by other ideologies.

The book contains legal and democratic issues accompanied by applicable laws. In addition, data on several legal issues are also presented, for example, in the discussion about the repatriation of Indonesian citizens who are former ISIS members to Indonesia. There is also data on the number of times elections were held and political parties in each election administration. In addition, there is also data on the percentage of public participation during the election. Public participation data during the election shows a decrease due to high abstentions. Evidence in the book is convincing because the author takes evidence from the data said by experts such as the head of the BNPT. In addition, the evidence also comes from the Law.

The author is a lecturer at IAIN Palopo and Andi Djemma University Palopo. The style of writing contains legal and democratic issues that have just occurred in Indonesia. The studies or facts presented by the author may need to be reconsidered by the reader. For example, a law needs to be ascertained whether the Law is actual and valid when the reader reads this book.

This book has the advantage of being the latest year (2020), containing material on various recent legal and democratic phenomena. The legal phenomena presented are also based on the Law that regulates these issues to increase readers' knowledge about the Law. Besides having advantages also has a weakness. The weakness is the lack of supporting images. Images are only presented at the beginning of each chapter. So readers get bored quickly. There are no conclusions at the end of the chapter.

Suggestions for the next reviewer, if there is a recent revision of the Future Format book (Notes on Indonesian Law and Democracy), you can search for the latest data from the author. Can add 
supporting images to make it easier for readers to understand the material. With a picture, readers will not get bored quickly. To make it easier for readers to understand the material, you can add conclusions in each chapter.

\section{REFERENCE}

1. Yusmad MA. Future Format (Notes on Indonesian Law and Democracy). 1st ed. Yogyakarta: Deepublish (CV Budi Utama Publishing Group); 2020. 104 bl.

\section{AUTHOR BIOGRAPHY}

Dr. H. Muammar Arafat Yusmad, SH, MH is the second son of HMS. Yusmad, SH, and Hj. Andi Nuryanti Yusmad. Born in Jambi, November 18, 1974. Undergraduate education at the Faculty of Law, Hasanuddin University Makassar (in 1993), a Masters in Law at the Postgraduate Program at Hasanuddin University Makassar (2005), a doctoral-level at the Doctor of Law Program (PDIH), Faculty of Law, Brawijaya University. His writing experience began in 2006 until now. Several works have been published in scientific journals, including the Journal of Law "Dinamika Hukum" Faculty of Law, Jenderal Soedirman University, Journal of Law and Sharia "Al-Ahkam," etc (1). 